\title{
Culturally Displaced Identity of the Protagonist in the Novel 'Wife'
}

\author{
Dr. Shirisha Deshpande
}

\author{
Assistant Professor, Department of Maths and Humanities, Chaitanya Bharathi Institute of Technology, Hyderabad, \\ Telangana. \\ deshpandeshirisha72@gmail.com
}

\begin{abstract}
Bharati Mukherjee was an Indian diasporic writer. Though she migrated to USA, her roots have always been in India, associated with the culture and tradition of the native country. As an expatriate writer her works project the cultural displacement faced by the immigrants and the impact that is left on them. Her novels project the different situations the migrated characters face, problems they overcome, the adjustments they make and the feeling of isolation.
\end{abstract}

The present paper discusses the impact of cultural displacement on the main protagonist Dimple das gupta in the novel Wife written by Bharati Mukherjee and published in the year 1975.My objective is to project the problem faced by the first generation of immigrants by studying the character Dimple das gupta and the impact of cultural displacement on the immigrants by using the tools of psycho-analytical theory.

Application of Psycho-analytical theory to literary texts helps the readers to study the characters and find out the reasons for different behaviours.According to Sigmund Freud it is clash of id, ego and superego which are the three parts of the human psyche that makes transformation of personalities that result in different behaviors'. If people experience these type of psychological clashes they do not come under normal personality. As the founder of psychiatry Sigmund Freud mentioned the functioning of the mind at various levels in terms of psychology and neurology.

The main protagonist Dimple das gupta lives in a fantasy world and makes dream as source of her living in the native country and in the alien country. Her dream takes a violent turn because of the suppressed desires and makes her a negative character. One of the reasons being the cultural displacement. She dreams a beautiful life and a good husband but when her dreams are shattered she kills her husband. She turns out to be a different personality altogether who cannot find happiness in her marriage either in Calcutta or in USA.

Keywords- Culture, Cultural displacement, dream, Immigrants, India, psycho-analytical theory, tradition, USA.

\section{INTRODUCTION}

The novel Wife written by Bharati Mukherjee narrates the theme of immigrant experience in USA. It is the story of a middle-class Bengali girl who migrates to USA after her marriage. Mukherjee got the idea of writing this novel when she returns from USA to India after a long stay in USA for a period of ten years. She found a new face of India different from the innocent one what she knew during her childhood. That time she could get the material for the novel. She recollects "quite by an accident, I heard the question that shaped my second novel-'what do Bengali girls do between the ages of eighteen and twentyone....."

The novel opens with a sarcastic note-"Dimple Dasgupta had set her heart on marrying a neurosurgeon". Dimple was very particular of marrying a neurosurgeon which depicts something unnatural. From the beginning of the novel we find that Dimple was not natural like other girls. All the time she used to think about marriage and it is going to change her life.

\section{METHODOLOGY AND MATERIALS}

Psychoanalytic dream interpretation is a part of psychoanalysis started by Sigmund Freud in the early part of the twentieth century. Psychoanalytic dream interpretation explains the way the subconscious mind works. According to Freud every dream represents a desire. Freud through his theory explained the unconscious wishes during the conscious state. In the sleep these unconscious desires are transformed into conscious form of dream. Sigmund Freud through Interpretation of dreams divided three different layers of the mind. The Unconscious, The pre-conscious, and The Conscious. According to psychoanalysis, the conscious mind controls the thought and emotion. According to Freud there is a continuous conflict between the 'ego' and the 'id' during sleep. 'Id' gets changed when it comes in contact with the external world. During sleep super ego is repressed because of the absence of the voluntary action and subconscious impulses become more and are pushed towards conscious state. 
III. MARRIAGE AND HER EARLY LIFE

"Marriage would bring her freedom, Cocktail parties on carpeted lawns, fund- raising dinners for noble charities. Marriage would bring her love. (Wife p.3). Dimple "thought of premarital life as a dress rehearsal for actual living. Years of waiting had already made her nervous, unnaturally prone to colds, coughs, and headaches".(Wife p3).

Dimple at the age of twenty feels bad that she has wasted all these years and didn't achieve anything in her life.Always she used to dream about the future husband who is going to provide all the comforts and luxuries. She was a student at that time but studies were very irritating for her.Finally, her father could find a good match for her. His name was Amit Basu who applied for American immigration. After Dimple's marriage, she moves to Amit's house.She feels uncomfortable with Amit's mother and sister. As per the Indian tradition her mother in law wanted to change her name to "Nandini".

She feels that when she moves to USA she would not face all these problems. Dimple lived in a fantasy world. When she comes to know the reality of her life all her dreams are shattered. She felt that waiting for marriage was better than getting married. One of her friend brought few magazines before she got married and showed her how young married brides decorated their bedrooms with good colours. "That was supposed to be the best part of getting married: being free and expressing yourself" (Wife p 20). She felt that marriage has robbed her off her dreams.

\section{DREAM AS A SOURCE OF LIVING}

As dream is like a guardian of sleep it gives a visual fantasy to the person. As Dimple had desires enveloped in the subconscious mind and as she could not express her feelings to Amit, she suppressed all her desires and her behaviour started affecting. She even tried to imagine Amit as her dream boy. Amit did not fit into the role of the husband, the type of the man Dimple had imagined in her fantasy world. When Amit was not at home she used to imagine the man of her dreams: She borrowed a forehead from an aspirin as, the lips, eyes and chin from a body builder and shoulders ad, the stomach and legs from a trousers ad and put the ideal man.( wife p 23)

As the time moves on Dimple becomes pregnant and the excitement of her marriage diminishes. In Indian tradition a woman feels happy when she becomes pregnant. It not only uplifts the social status of a woman but also makes her feel of motherhood. Unlike other Indian woman Dimple does not feel happy of her pregnancy "she thought of ways to get rid of ... whatever it was that blocked her tubes and pipes"(Wife p 31)

We can say that her mental condition was not good. She becomes hysteric she kills a mice who looked pregnant:
She pounded and pounded the baby clothes until a tiny gray creature ran out of the pile, leaving a faint trickle of blood on the linen. She chased it to the bathroom. She shut the door, so it would not escape from her this time.... "I'll get you" she screamed. "There is no way out of this, my friend...." And in an outburst of hatred, her body shuddering, her wrist taut with fury, she smashed the top of a small grey head (Wife p35).

As she was not happy with her marriage she developed a kind of hatred towards Amit.She hated her pregnancy and also developed violence which is clearly visible in the act of killing mice. She thought of migrating, but she didn't want to carry her past. Even she goes to the extent of terminating her pregnancy.

She had skipped rope until her legs grew numb and her stomach burned; then she had poured water from the heavy bucket over her head, shoulders, over the tight little curve of her stomach. She had poured until the last of the blood washed off her legs; then she had collapsed (Wife p 42).

Finally the day of moving to USA came and Dimple was very happy to find herself in New York. She never moved out of Calcutta till now and going to New York was a very big thing for her. She was astonished to see the beautiful city of New York:

She had never seen such bigness before; the bigness was thrilling and a little scary as well. She could not imagine the kind of people who had conceived it and who controlled it (Wife $\mathrm{p}$ 52).

\section{DISPLACEMENT CAUSED DUE TO MIGRATION}

Being in New York was a totally different kind of experience to Dimple. It was an exposure to a different society and culture. Amit remains jobless even after moving to USA and his frustration becomes more. Even this is one of the reasons that spoil the relationship between both. Dimple used to pass the time by watching Television or reading newspapers. She was afraid of American atmosphere.

As the time passes Dimple is heartbroken and feels that she got deceived in the marriage and Amit is not the type what she dreamt. She started feeling that "she hated the sens' apartment, sofa-bed, the wall to wall rug" (Wife $\mathrm{p}$ 88).She thinks that she utterly failed in her marriage with Amit:

She was bitter that marriage had betrayed her, had not provided all the glittery things she had imagined, had not brought her cocktails under canopied skies and three A.M. drives to dinzy 
restaurants where they sold devine Kababs rolled in $\operatorname{roti}$ (Wife p 102).

She went to a party where she got an opportunity to get exposure to the outside world and study the attitudes of people. She could meet a lady called Ina, notorious wife of Bijoy Mullick. Unknowingly Dimple started walking into the footsteps of Ina Mullick who was a modern woman with crazy ideas. Everything she started looking through the eyes of Ina.The last part of the novel narrates scenes that are filled with Dimple's abnormality. Even though Amit gets a job she is not satisfied with her life. For small things she gets irritated and one day she loses her temper and says:

I feel sort of dead inside and you can do is read the paper and talk to me about food. You never listened to me. You have never listened to me You hate me. Don't deny it; I know you do. You hate me because I'm not fat and fair (Wife p110). The above said words came out of frustration. She developed an inferiority complex and felt that she is unable to win her husband's heart. Amit too never tried to understand the mentality of a woman. He thinks that by providing material comforts is sufficient and he ignores her material comforts. He very rarely takes her out of the house and says that:

You must go out, make friends, do something constructive, not stay at home and think about Calcutta.( Wife p111).

She started feeling uncomfortable even in America and became nostalgic. "how could she live in a country...where every other woman was a stranger, where she felt different, ignorant, exposed to ridicule in the elevator?"( Wife p112). She became totally restricted to the four walls of the apartment and media became her only companion. Whenever she had free time she used to dream of Amit but could not do so because:

Amit did not feed her fantasy life; he was merely the provider of small material comforts. In bitter moments she ranked husband, blender, color TV, cassette, tape recorder, stereo, in their order of convenience (Wife p 113).

Dimple started getting irritated for small things. In the words of Linda Sandler:

Dimple emigrates to the electronic age with her traditional values almost intact, only partly modified by the pop culture of modern Calcutta, she is unable to make the transition from Before to After and chooses violence as a "problemsolving" device....

Dimple failed miserably to assimilate with America:

She is scared of self-service elevators, of policemen, of gadgets and appliances She does not want to wear western clothes as she thinks she would be mistakenly taken for a Puerto Rican. She does not want to loose her identity but feels isolated, trapped, alienated, and marginalised.

Her depression starts growing. She hides everything from Amit whatever is going on in her mind:

She does not tell him about these imaginary beginnings. She didn't tell him about her immoderate day time sleeping either. They were unspeakable failings. She thought of them as deformities-sinister, ugly, and wicked. (Wife $\mathrm{p}$ 115)

Asnani described the mental state of Dimple as 'dilemma of cultures'- "Dimple is entrapped in a dilemma of tensions between American culture and society and the traditional constraints surrounding an Indian wife, between a feminist desire to be as sertive and independent and the Indian need to be submissive and self- effacing." Whenever she used to feel lonely Dimple felt of committing suicide. She started embracing all evil kind of thoughts like darkness, evil, sinter- murder, suicide. Like a Television advertisement she wants to get rid of her life. Except media she doesn't want to trust anyone. Even "Her own body seemed curiously alien to her filled with hate, malice, an insane desire to hurt, yet weightless, almost airborne" (Wife p 117).

Watching Television made her more psychic. She always used to get the thoughts like rape, somebody breaking the window and coming into her room. When Amit pointed out at her foolishness she says: "In America anything is possible. You can be raped and killed on any floor." (Wife p129) As the novel proceeds we find lot of change in Dimple's behaviour. She started going out with Ina and Milt a foreigner. She adopts western outfit, wears purple coloured tinted sunglasses. Each and every encounter of Dimple with Milt brought them closer. She started extra marital affair with Milt. "The purple tinted sunglasses are perhaps the most typical index of American culture. For Dimple, they are a disguise, borrowed from the west, just like Marsha's clothes and the apartment in which she is living". This relation makes her neurotic and fails to differentiate between the real life and the picture depicted on Television. She also becomes alienated.

Dimple started feeling gloomier day by day. "Her life was slow, full of miscalculations" (Wife p178). Amit could make out the changes in her and felt that it was because of culture shock. She started planning the murder of her husband. She becomes violent. She wanted to kill her husband just like what she sees on television. As she becomes neurotic the killing of her husband becomes fancy. She could not differentiate the reality and the imaginary world. 
Dimple becomes a psycho and by stabbing seven times she frees herself from the marriage. She becomes a victim of neurotic disorder by watching the advertisements. May be Dimple would have lead a more happier life if she would have stayed back in India. She would have leaded a happier life with her husband. Her migrating to America and the underlying suppressed desires brought her violence out. Her emotions brought a kind of madness, nightmares extramarital affairs in her. She takes revenge of her unfulfilled desires by murdering her husband. She becomes mentally unstable and indulges in such a violent act. She was very much conscious of being more and more alienated from the surroundings: "she was a pitiful immigrant among demanding appliances."(Wife 186) in her flat that expatriation to America had brought her to.

\section{CONCLUSION}

Cultural displacement made Dimple more neurotic and her personality disorders came out in the alienated land because she could not find a close associate with whom she could share her feelings and her husband was not the type of the person who could understand the expectations of Dimple. In a quest for a new identity and caught between the native culture and the alien culture these type of characters try to adopt the new culture. In the process they undergo psychological transformation which is often involved with violence as in the case of Dimple. The study with the application of psychoanalysis gave the novel a new perspective. The struggle of the protagonist Dimple starts with her inner conflict of the mind and it takes a violent shape because of her unfulfilled desires.

\section{REFERENCES}

[1] Freud, Sigmund. (1949). The Ego and The Id. Trans.by Joan Riviere. London: The Hogarth Press, 1949.

[2] ---. "The Origin and Development of Psychoanalysis" The American Journal of Psychology. Published by University of Illinois Press, Vol. 21, No. 2, April, 1910. Jstor, Web. Pp. 181-218. H

[3] Jain, Jasbir. "Foreignness of Spirit: the world of Bharati Mukherjee ees Novels," The Journal of Indian Writings in English 13 .2 (July 1989):15

[4] Linda Sandler. "Violence as a Device for Problem Solving" in Saturday Night, 90, 5 (October 1975), 75.

[5] Linda Sandler. "Violence as a Device for Problem Solving" in Saturday Night, 90, op. Cit., p 75.

[6] Mukherjee, Bharati. Wife, Delhi: Sterling, 1976.

[7] Mukherjee, Bharati. Wife (Boston: Houghton Miffin, 1975; Penguin Indian reprint), p.3
[8] Quoted in Anne Mandel, "Bharati Mukherjee" in W.H. New, ed.DLB: Canadian Writers Since 1960, Vol.60 (Detroit :Gale Research Company, 1986),p.267.

[9] Shyam M. Asnani et al. "Identity crisis in The Nowhere Man and Wife", Language Forum,1-2 (Jan-Dec. 1992), 42. 